\title{
Aspek Morfometri Dan Tingkat Kematangan Gonad Rajungan (Portunus pelagicus) Linnaeus, 1758 (Malacostraca:Portunidae) di Perairan Betahwalang Demak
}

\author{
Muhammad Amanun Tharieq*, Sunaryo, Adi Santoso \\ Departemen IImu Kelautan, Fakultas Perikanan dan IImu Kelautan, Universitas Diponegoro \\ JI. Prof. H. Soedarto S.H, Tembalang, Semarang, Jawa Tengah 50275 Indonesia \\ *Corresponding author, e-mail : muhammadamanun@student.undip.ac.id
}

\begin{abstract}
ABSTRAK: Rajungan (P. pelagicus, Linnaeus, 1758) adalah salah satu hasil perikanan utama di Betahwalang, Demak. Penangkapan rajungan diduga dilakukan secara intensif oleh nelayan di Des Betahwalang, maka diperlukan langkah pengelolaan yang tepat untuk menjaga kelestarian dan konservasi rajungan. Informasi aspek morfometri rajungan bias digunakan sebagai salah satu acuan dalam pengelolaan rajungan berkelanjutan. Tujuan penelitian adalah untuk mengkaji tingkat kematangan gonad dan morfometri rajungan yang dilaksanakan pada bulan Juli - September 2019 di Desa Betahwalang, Demak. Penelitian menggunakan metode survey dengan analisis yang bersifat deskriptif yang dilakukan secara "time-series". Pengamatan sampel rajungan sebesar $10 \%$ dari hasil tangkapan yang didaratkan oleh setiap nelayan di pengepul rajungan. Total rajungan yang diamati 5.480 ekor terdiri dari betina 2.960 ekor dan jantan 2.388 ekor. Hasil penelitian menunjukkan pertumbuhan rajungan jantan bersifat allometrik positif, sedangkan rajungan betina cenderung bersifat allometrik negatif dengan seks rasio relatif seimbang. Rajungan betina diduga mengalami pertama kali matang gonad pada selang kelas lebar karapas $70-79 \mathrm{~mm}$. Sampel pengamatan fekunditas dan kematangan telur pada 126 ekor rajungan betina bertelur. Kematangan telur dilihat dari pigmen warnanya secara berurutan mulai pigmen warna kuning, orange, coklat dan hitam, serta berdasarkan ukuran diameter telur. Fekunditas telur memiliki korelasi yang sangat kuat terhadap lebar karapas yang berarti semakin besar ukuran rajungan, maka jumlah telur semakin banyak. Selama penelitian masih ditemukan rajungan "undersize" sebesar 18\% (981 ekor) dan rajungan betina bertelur sebesar 24\% (716 ekor), yang berarti nelayan di Desa Betahwalang belum menerapkan kriteria dan ukuran layak tangkap sesuai dengan peraturan yang berlaku.
\end{abstract}

Kata kunci: Rajungan; Portunus pelagicus; Morfometri; Betahwalang

\section{Morphometric and Gonad Maturity Level of Blue Swimming Crab (Portunus pelagicus) Linnaeus, 1758 (Malacostraca:Portunidae) in Betahwalang Waters, Demak}

ABSTRACT: Blue swimming crab (P. pelagicus, Linnaeus, 1758) is one of main fisheries products in Betahwalang, Demak. High-intensity levels of catching the blue swimmer crab by fisherman may need sustainable management to protect and conserve the population. The purpose of this study was to determine about gonad maturity level and morphometrical aspect of blue swimming crab started from July - September 2019. There's a descriptive survey method used in this study with time-series observations. The sample size is about $10 \%$ of the total number landed crab from each fisherman. The total sample are 5.348 that consist of 2.960 female crabs and 2.388 male crabs. The results showed the male crabs has a positive allometric on growth parameters, but the females have an allometric positive and negative growth parameters, and balanced sex-ratio. Female crabs may reach the first matured gonad level between $70-79 \mathrm{~mm}$ of carapace width. Fecundity and egg's maturity observation used 126 berried female crabs. The egg's maturity based on the pigment color started from yellow, became orange, brown and black also by egg diameter increase. The analysis showed that female crab fecundity has a strong correlation to the increase of carapace width, which means carapace width increase followed by egg's amount increasing. During the study, it was found about 18\% (981 crabs) the undersize crabs (<100 mm) and 24\% (716 crabs) the berried female crabs, which means the Betahwalang fisherman hasn't applied the rule yet.

Keywords: Blue Swimming Crab; Portunus pelagicus; Morphometric; Betahwalang 


\section{PENDAHULUAN}

Rajungan dari spesies Portunus pelagicus merupakan salah satu komoditas hasil perikanan yang penting karena mempunyai nilai ekonomi tinggi dan permintaan pasar di dalam maupun luar negeri cukup tinggi. Data Badan Pusat Statistik pada tahun 2018, menunjukkan volume ekspor rajungan periode tahun 2012 - 2017 mengalami pertumbuhan sebesar 0,67\% per tahun, dengan nilai ekspor yang tumbuh sebesar $6,06 \%$ per tahun. Ekspor rajungan pada periode Januari September 2018 mencapai volume sekitar 21.570 ton atau senilai USD 370,14 juta, dengan negara tujuan utama adalah Amerika Serikat dengan persentase sebesar $49,44 \%$ dan menyumbang devisa sebesar USD 280,82 juta (KKP, 2018). Faktor harga komoditas yang tinggi dan pasar yang jelas, dapat mendorong terjadinya peningkatan eksploitasi rajungan dari alam (wild catch) di wilayah perairan secara terus menerus tanpa memperhatikan kondisi sumber daya dan lingkungan.

Perairan Betahwalang memiliki sumber daya rajungan yang cukup potensial. Aktifitas nelayan rajungan di Betahwalang dinilai cukup tinggi, dengan penangkapan rajungan yang dilakukan hampir setiap hari dan terbagi atas dua waktu keberangkatan yaitu pagi dan malam hari (Edi et al., 2018). Penggunaan alat tangkap dengan tingkat selektifitas rendah seperti jaring arad masih banyak digunakan oleh nelayan rajungan, berdasarkan penelitian sebelumnya oleh Ningrum et al. (2015) dengan masih banyak ditemukan rajungan under size dan betina bertelur yang ditangkap. Tingginya aktifitas penangkapan rajungan dan kurangnya selektifitas terhadap hasil tangkapan membuat ancaman terhadap stok sumber daya yang akan semakin menurun dan ekosistem yang akan tertekan.

Upaya untuk menjaga kelestarian rajungan di perairan Betahwalang sangat diperlukan, oleh sebab itu dibutuhkan informasi yang dapat mendukung terkait pengelolaan rajungan berkelanjutan. Kajian tentang morfometri dan tingkat kematangan gonad rajungan ( $P$. pelagicus) di perairan Betahwalang, Demak sangat diperlukan sebagai salah satu acuan dalam mengetahui kondisi populasi rajungan dan dapat digunakan sebagai informasi dalam pengelolaan sumber daya rajungan berkelanjutan oleh pihak yang berkepentingan. Penelitian ini bertujuan untuk mengkaji morfometri dan tingkat kematangan gonad pada rajungan yang meliputi distribusi ukuran lebar karapas, hubungan lebar karapas dan berat, nisbah kelamin, tingkat kematangan gonad dan tingkat kematangan telur rajungan betina hasil tangkapan nelayan dari perairan Betahwalang Demak.

\section{MATERI DAN METODE}

Metode yang digunakan dalam penelitian adalah metode survey, yaitu observasi atau pengamatan langsung dalam rangka pengumpulan data untuk penelitian (Kembaren et al., 2012). Data yang telah terkumpul kemudian dilakukan analisis secara deskriptif untuk memberikan gambaran kondisi perikanan rajungan di perairan Betahwalang. Sampel rajungan ( $P$. pelagicus) yang digunakan dalam penelitian didapatkan dari lima pengepul rajungan yang didaratkan oleh nelayan di Desa Betahwalang, Demak. Pengamatan sampel rajungan dilakukan dari Juli September 2019 dengan pengambilan sampel secara time-series. Periode pengumpulan sampel dilakukan selama 5 hari yang dilaksanakan pada minggu pertama dan ketiga setiap bulannya.

Pengukuran lebar karapas rajungan mengacu pada PERMEN-KP No. 56 tahun 2016. Pengukuran lebar karapas menggunakan penggaris dengan ketelitian 0,5 mm, sedangkan untuk mengukur berat digunakan timbangan digital dengan ketelitian $100 \mathrm{mg}$. Pengamatan jenis kelamin dengan melihat bentuk abdomen rajungan, dimana jantan memiliki bentuk abdomen segitiga meruncing sedangkan pada betina bentuknya menyerupai "puncak" tugu monas (Zairion et al., 2014), Pengamatan tingkat kematangan gonad (TKG) dilakukan pada sampel rajungan betina dengan cara mengamati morfologi pada bentuk dan kondisi abdomennya (Kunshook et al., 2014). Pengamatan kematangan telur dilakukan secara analisis laboratorium untuk mengukur diameter dan fekunditas telur rajungan berdasarkan metode menurut Hamid et al. (2015). Pengambilan data parameter kualitas air meliputi suhu $\left({ }^{\circ} \mathrm{C}\right)$, Salinitas (ppt), $\mathrm{pH}$, dan $\mathrm{DO}(\mathrm{mg} / \mathrm{L})$ dilakukan dengan ikut melaut bersama nelayan selama enam kali pengamatan yang dilaksanakan pada akhir pekan minggu pertama dan minggu ketiga. 
Analisis data yang digunakan meliputi, (1) Distribusi frekuensi ukuran lebar karapas. Selang kelas, nilai tengah, dan frekuensi diperoleh dengan menggunakan software Microsoft Excel 2016. (2) Analisis hubungan lebar karapas dan berat tubuh. Hubungan lebar-berat digunakan untuk menggambarkan sifat atau pola pertumbuhan rajungan dalam dua bentuk yaitu isometrik dan allometrik dengan menggunakan persamaan Effendie (2002), kemudian dilakukan Uji t-test untuk analisis tingkat signifikansinya. (3) Analisis rasio rajungan jantan dan betina (sex ratio). Nisbah kelamin rajungan jantan dan betina dihitung menggunakan rumus Effendie (2002) dan dilanjutkan menggunakan Uji Chi-square (Kamrani et al., 2010) untuk mengetahui keseimbangan nisbah kelamin yang didapatkan. (4) Analisis tingkat kematangan gonad. Tingkat kematangan gonad dianalisis secara deskriptif dan digambarkan dalam bentuk grafik untuk mengetahui komposisi TKG rajungan betina berdasarkan kelas lebar $(\mathrm{mm})$ dan kelas berat $(\mathrm{g})$. (5) Tingkat kematangan telur dan fekunditas. Kematangan telur rajungan dilihat berdasarkan warna dan ukuran diameter, sedangkan fekunditas dilakukan analisis hubungan dengan lebar karapas, berat tubuh dan berat telur (Hamid et al., 2015).

\section{HASIL DAN PEMBAHASAN}

Hasil penelitian menunjukkan bahwa jumlah rajungan didapatkan sebanyak 5.348 ekor yang terbagi atas betina 2.960 ekor dan jantan 2.388 ekor. Hasil tangkapan rajungan selama penelitian memiliki jumlah dan komposisi yang berbeda-beda antara rajungan jantan dan betina, hal tersebut diduga berkaitan dengan perbedaan musim dimana pada bulan Juli merupakan musim Timur, kemudian pada bulan September merupakan musim peralihan (Zairion et al., 2014). Menurut de Lestang et al. (2003), perbedaan komposisi rajungan juga diduga disebabkan oleh proses migrasi dan preferensi lingkungan yang berbeda antara rajungan jantan dan betina.

Hasil pengukuran lebar karapas rajungan diperoleh 13 kelas ukuran berdasarkan ukuran layak tangkap rajungan pada PERMEN-KP No. 56 Tahun 2016. Pengamatan pada rajungan jantan mengalami pergeseran modus kelas lebar karapas, dimana pada bulan Juli dan Agustus didapatkan modus kelas lebar karapas yaitu 120 - 129 mm, sedangkan pada bulan September modus lebar karapas pada kelas 100 - 109 mm. Pergeseran modus lebar karapas pada rajungan jantan diduga disebabkan oleh adanya pengaruh perubahan kondisi seperti ketersediaan makanan, migrasi, musim pemijahan maupun faktor lain seperti aktifitas penangkapan. Pengamatan pada rajungan betina selama penelitian memiliki modus kelas lebar karapas yaitu 110 - $119 \mathrm{~mm}$. Perbedaan modus kelas lebar karapas pada rajungan jantan dan betina, menunjukkan bahwa pada ukuran lebar karapas jantan lebih besar. Hasil tersebut sesuai dengan pernyataan Hermanto (2004), perbedaan ukuran dimana rajungan jantan lebih besar dibandingkan rajungan betina disebabkan salah satunya oleh aktivitas makan rajungan jantan yang lebih tinggi.

Rajungan di perairan Betahwalang diduga berasal dari generasi kelahiran yang berbeda, hal ini berdasarkan pengamatan pergeseran modus kelas lebar karapas pada data ukuran lebar karapas dari bulan Oktober 2018 sampai dengan September 2019. Asumsi yang digunakan pada analisis kohort yaitu jika modus lebar karapas bergeser ke kanan menandakan rajungan mengalami pertumbuhan dan masih berasal dari generasi yang sama, tetapi jika modus bergeser ke kiri diduga merupakan generasi yang berbeda. Menurut Sunarto (2012), adanya variasi ukuran menunjukkan bahwa rajungan yang tertangkap tidak dihasilkan dari satu kohort yang sama, selain itu juga dapat mengindikasikan bahwa rajungan memijah tidak dalam satu waktu yang sama.

Ukuran lebar karapas rajungan yang ditemukan selama pengamatan masih terdapat rajungan yang tidak masuk dalam ukuran layak tangkap (undersize) yang ditetapkan oleh pemerintah dalam PERMEN-KP No. 56 Tahun 2016 yang menyatakan bahwa ukuran minimum lebar karapas rajungan yang boleh ditangkap adalah sebesar $100 \mathrm{~mm}$. Sebanyak 981 ekor rajungan atau $18 \%$ dari total sampel yang diamati selama penelitian belum sesuai dengan peraturan yang berlaku. Dapat disimpulkan bahwa nelayan di Betahwalang belum melaksanakan sebagaimana peraturan yang ada, dan apabila kegiatan penangkapan tanpa memperhatikan kelestarian rajungan terus dilakukan dapat mengakibatkan stok sumber daya di alam akan semakin menurun. Penangkapan terhadap rajungan kecil dikhawatirkan akan mengganggu populasi rajungan dengan tidak memberikan kesempatan rajungan untuk tumbuh dan berkembangbiak. 
Hasil analisis hubungan lebar karapas dan berat tubuh selama penelitian didapatkan pola pertumbuhan rajungan jantan bersifat allometrik positif, sedangkan rajungan betina cenderung bersifat allometrik negatif. Pola pertumbuhan rajungan dapat diketahui berdasarkan nilai b, yang diduga dapat dipengaruhi oleh beberapa faktor seperti ketersediaan makanan, kondisi habitat pola pemijahan dan faktor lain seperti aktifitas penangkapan oleh nelayan. Hasil analisis pada rajungan jantan menunjukkan tidak adanya pengaruh perbedaan waktu pengamatan terhadap pola pertumbuhannya, sedangkan pada rajungan betina mengalami perubahan pola pertumbuhan yang diduga disebabkan oleh perbedaan waktu pengamatan serta faktor pemijahan.

Tabel 1. Komposisi Rajungan (ekor) Jantan dan Betina Hasil Tangkapan Nelayan dari Perairan Betahwalang Demak Bulan Juli sampai September 2019.

\begin{tabular}{|c|c|c|c|c|}
\hline No & Bulan & Betina (ekor) & Jantan (ekor) & Jumlah (ekor) \\
\hline 1 & Juli & 912 & 879 & 1.791 \\
\hline 2 & Agustus & 1.041 & 737 & 1.778 \\
\hline 3 & September & 1.007 & 772 & 1.779 \\
\hline \multicolumn{2}{|c|}{ Jumlah (ekor) } & 2.960 & 2.388 & 5.348 \\
\hline
\end{tabular}

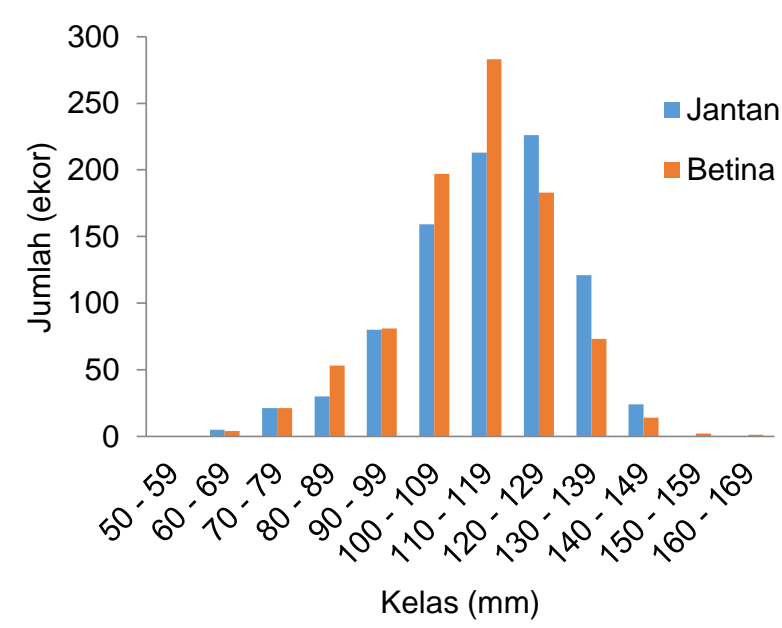

(A)

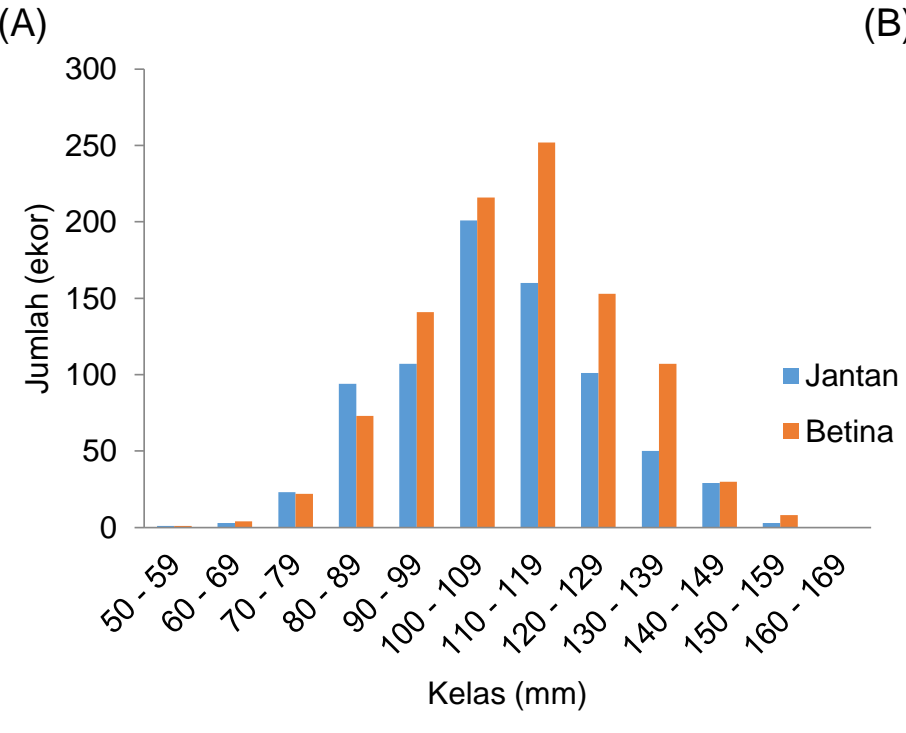

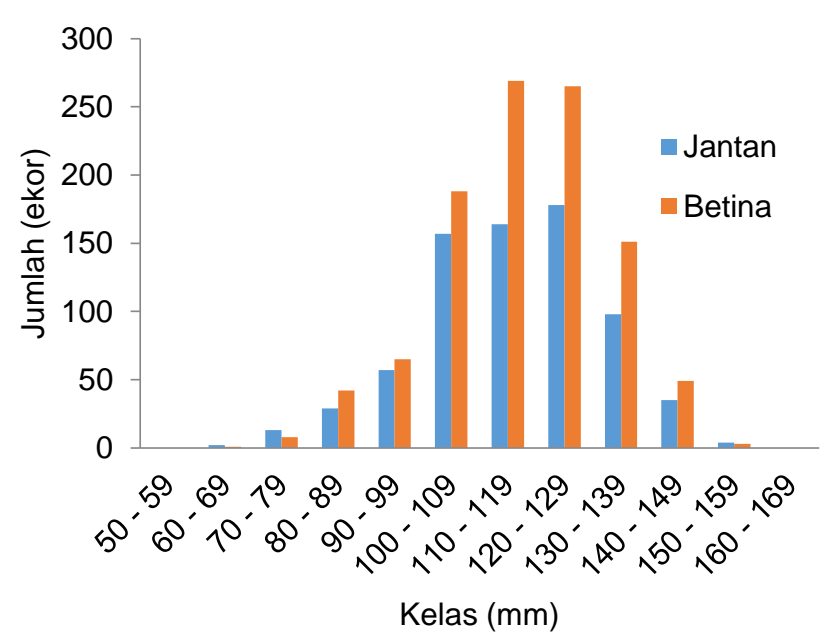

(B)

(C)

Gambar 1. Distribusi Ukuran Kelas Lebar Karapas Rajungan ( $P$. pelagicus) Jantan dan Betina di Perairan Betahwalang Demak pada Juli (A), Agustus (B) Bulan September (C) 2019. 

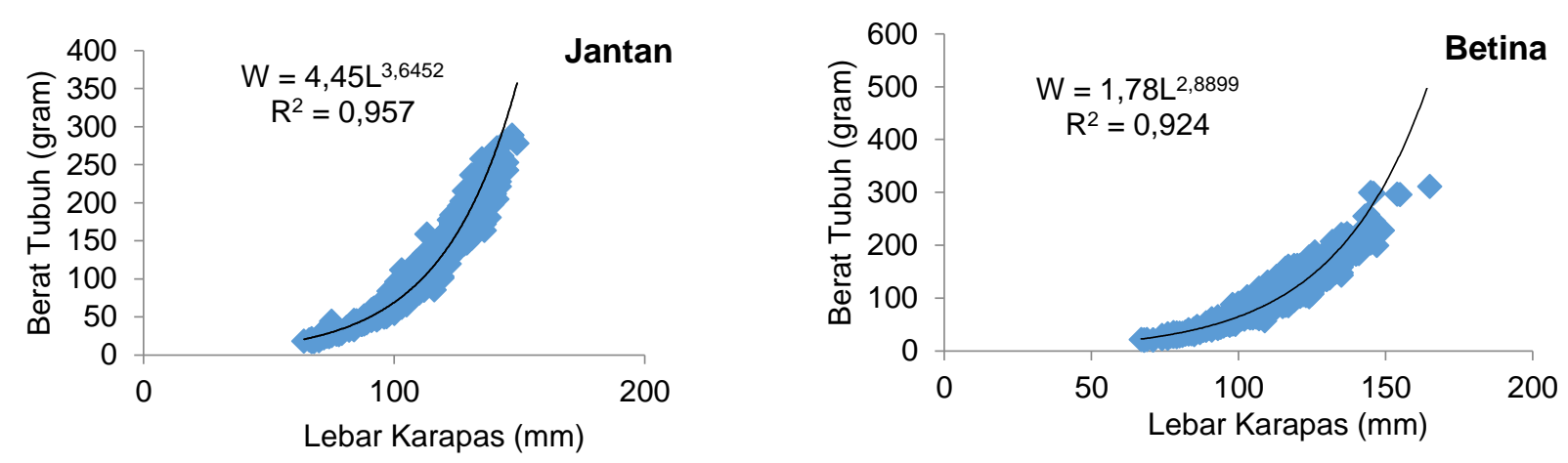

(Juli 2019)
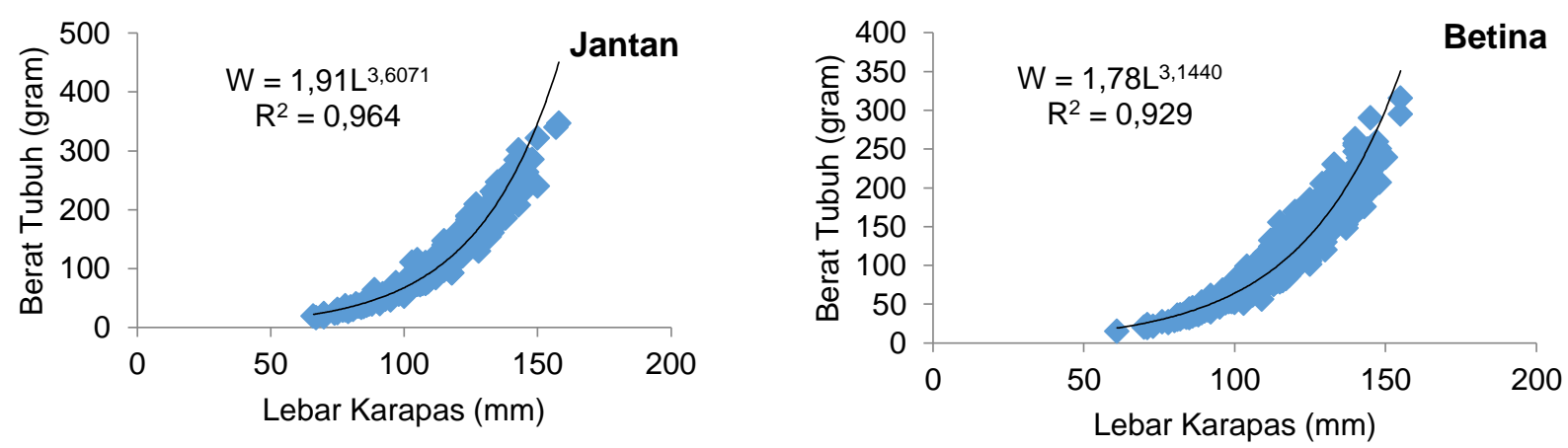

(Agustus 2019)
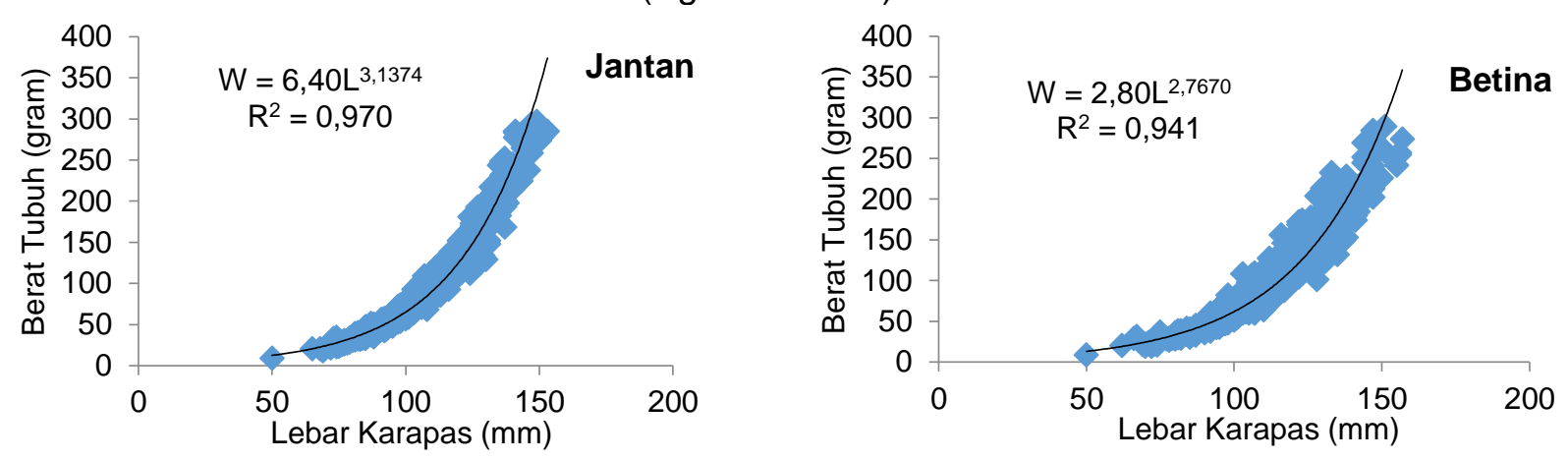

(September 2019)

Gambar 2. Hubungan Lebar Karapas dan Berat Tubuh Rajungan Jantan dan Betina Hasil Tangakapan Nelayan dari Perairan Betahwalang, Demak

Menurut Ernawati et al. (2014), bahwa perbedaan sifat pertumbuhan yang terjadi pada rajugan dapat dipengaruhi oleh pengaruh faktor lingkungan, ketersediaan makanan, suhu dan salinitas perairan, jenis kelamin dan reproduksi serta area penangkapan. Rajungan betina dengan pola pertumbuhan allometrik negatif berarti pertumbuhan lebar karapasnya lebih cepat dibandingkan pertambahan berat tubuh, yang diduga dipengarhui oleh aktifitas reproduksi dimana rajungan betina akan moulting ketika akan melakukan perkawinan. Pergantian cangkang mengakibatkan lebar karapas rajungan betina lebih cepat tumbuh, setelah proses perkawinan rajungan betina akan makan untuk memenuhi kebutuhan nutrisi dan proses pemijahan sehingga berat tubuhnya akan semakin meningkat.

Nisbah kelamin merupakan perbandingan antara jumlah rajungan jantan dan betina dalam suatu populasi dan penting diketahui karena berpengaruh terhadap kestabilan populasi rajungan pada suatu perairan. Hasil penelitian menunjukkan bahwa rasio rajungan jantan dan betina relative seimbang, tetapi pada bulan Agustus ditemukan rajungan betina lebih mendominasi. Menurut Sumpton et al. (1994), perbedaan komposisi rajungan jantan dan betina pada suatu perairan diduga disebabkan oleh adanya perbedaan perilaku individu rajungan, aktifitas penangkapan, mortalitas dan rekruitmen di alam. Variasi nisbah kelamin rajungan salah satunya disebabkan oleh 
Tabel 2. Hubungan Lebar Karapas dan Berat Tubuh Rajungan Hasil Tangkapan Nelayan dari Perairan Betahawalang, Demak

\begin{tabular}{|c|c|c|c|c|c|c|}
\hline Bulan & Kelamin & $b$ & a & $\mathrm{R}^{2}$ & $\mathrm{~W}=\mathrm{aL}^{\mathrm{b}}$ & Pola Pertumbuhan \\
\hline \multirow{2}{*}{ Juli } & Jantan & 3,465 & 4,45 & 0,957 & $4,45 L^{3,465}$ & Allometrik Positif \\
\hline & Betina & 2,899 & 1,78 & 0,924 & $1,78 \mathrm{~L}^{2,889}$ & Allometrik Negatif \\
\hline \multirow{2}{*}{ Agustus } & Jantan & 3,607 & 1,91 & 0,964 & $1,91 \mathrm{~L}^{3,607}$ & Allometrik Positif \\
\hline & Betina & 3,144 & 1,78 & 0,929 & $1,78 \mathrm{~L}^{3,144}$ & Allometrik Positif \\
\hline \multirow{2}{*}{ September } & Jantan & 3,137 & 6,40 & 0,970 & $6,40 \mathrm{~L}^{3,137}$ & Allometrik Positif \\
\hline & Betina & 2,767 & 2,80 & 0,941 & $2,80 L^{2,767}$ & Allometrik Negatif \\
\hline
\end{tabular}

Tabel 3. Rasio Rajungan Jantan dan Betina Hasil Tangkapan Nelayan dari Perairan Betahwalang, Demak

\begin{tabular}{|c|c|c|c|c|c|c|c|}
\hline \multirow{2}{*}{$\begin{array}{l}\text { Waktu pengamatan } \\
\text { (bulan) }\end{array}$} & \multicolumn{2}{|c|}{$\begin{array}{l}\text { Jumlah } \\
\text { (ekor) }\end{array}$} & \multicolumn{2}{|c|}{$\begin{array}{l}\text { Nisbah Kelamin } \\
\text { (Rasio) }\end{array}$} & \multirow[t]{2}{*}{$\begin{array}{c}\mathrm{X}^{2} \\
\text { hitung }\end{array}$} & \multirow[t]{2}{*}{$X$ tabel } & \multirow[t]{2}{*}{ Keputusan } \\
\hline & $\mathrm{J}$ & $B$ & $\mathrm{~J}$ & B & & & \\
\hline Juli & 879 & 912 & 1 & 1,03 & 0,60 & 44,75 & Seimbang \\
\hline Agustus & 737 & 1.041 & 1 & 1,41 & 51,97 & 44,42 & Tidak Seimbang \\
\hline September & 772 & 1.007 & 1 & 130 & 31,04 & 44,45 & Seimbang \\
\hline
\end{tabular}

migrasi rajungan betina pada beberapa periode dalam satu tahun. Migrasi rajungan betina dipengaruhi oleh proses pemijahan dan penetasan telur yang membutuhkan kadar salinitas perairan yang lebih tinggi.

Rajungan betina pada penelitian ini ditemukan paling banyak pada bulan Agustus 2019 . Hasil ini didukung penelitian sebelumnya oleh Damora et al. (2016) di perairan Lampung Timur, dimana sebaran nisbah kelamin pada rajungan betina dapat terlihat pada setiap periode dua sampai tiga bulan komposisi rajungan betina cenderung meningkat yaitu pada bulan Januari, April dan Agustus. Ketidakseimbangan rasio jantan dan betina berdasarkan hasil tangkapan oleh nelayan perlu diperhatikan, semakin banyaknya rajungan betina tertangkap dan kurangnya selektifitas nelayan terhadap kriteria hasil tangkapan rajungan betina dapat mengganggu keseimbangan populasi dan menghambat proses rekruitmen rajungan di alam.

Rajungan betina umumnya ditemukan dengan tingkat kematangan gonad berbeda-beda yang dipengaruhi oleh perubahan musim. Hasil penelitian selama periode Juli sampai September 2019 didapatkan komposisi tingkat kematangan gonad (TKG) rajungan betina dengan TKG 1 (immature) sebesar 11\% (311 ekor), TKG 2 (mature) sebesar 65\% (1.933 ekor) dan TKG 3 (ovigerous) sebesar 24\% (716 ekor). Rajungan betina dengan TKG 1 dengan jumlah terkecil ditemukan pada pengamatan bulan Agustus, yang diduga berkaitan dengan pola migrasi rajungan betina dalam proses reproduksinya. Rajungan betina belum matang gonad akan mulai melakukan migrasi dari pesisir menuju perairan yang lebih dalam untuk melakukan proses perkawinan (Ernawati et al., 2014). Rajungan betina dengan TKG 1 pada penelitian ini umumnya ditemukan pada selang lebar karapas $80-89 \mathrm{~mm}$. Hasil ini menjadi salah satu alasan ditetapkannya PERMEN-KP No. 56 Tahun 2016 tentang minimum ukuran layak tangkap rajungan yaitu $100 \mathrm{~mm}$, karena rajungan dengan ukuran dibawah $100 \mathrm{~mm}$ tersebut umumnya belum matang gonad sehingga apabila terus dilakukan penangkapan dikhawatirkan akan menghambat proses rekruitmen dan mempengaruhi populasi rajungan.

Tingkat kematangan gonad rajungan betina selama penelitian didominasi oleh rajungan betina dengan TKG 2 (matang gonad) dan jumlah tertinggi didapatkan pada pengamatan bulan Agustus sebanyak 710 ekor. Hasil tersebut didukung dengan penelitian sebelumnya oleh Ernawati et al. (2014), yang menyatakan bahwa rajungan betina matang gonad ditemukan cenderung banyak ditemukan dalam satu tahun siklus adalah pada bulan Januari, April dan Agustus. Banyaknya rajungan betina matang gonad pada bulan Agustus diduga menandakan bahwa pada 
bulan sebelumnya rajungan telah mengalami proses perkawinan dan pematangan gonad. Rajungan betina matang gonad pada penelitian ini umumnya ditemukan pada kelas lebar karapas 110-119 mm, dengan kelas lebar terkecil ditemukan pada bulan Juli yang diduga rajungan betina dari Perairan Betahwalang mulai matang gonad pada ukuran lebar karapas $70-79 \mathrm{~mm}$. Ukuran betina matang gonad tersebut tergolong kecil $(<100 \mathrm{~mm})$ yang diduga mengalami tekanan oleh aktifitas penangkapan, sehingga rajungan betina mengalami matang gonad bahkan bertelur lebih cepat.

Rajungan betina bertelur pada penelitian ini didapatkan sejumlah 716 ekor atau $244 \%$ dari total rajungan betina yang diamati. Telur rajungan betina dari Perairan Betahwalang umumnya ditemukan dengan 4 komposisi warna yaitu kuning, orange, coklat dan abu kehitaman. Warnawarna telur tersebut menandakan tingkat kematangannya, dimana telur rajungan pertama keluar pada abdomennya berwarna kuning, kemudian semakin matang dan berubah menjadi orange, coklat dan hitam yang diperkirakan akan menetas dalam waktu kurang lebih 2 hari (Ikhwanuddin et al., 2012). Perubahan warna pada telur rajungan disebabkan oleh konsumsi dari kuning telur yang selanjutnya berkembang menjadi pigmen mata yang berwarna hitam. Tingkat kematangan telur pada rajungan betina selain dari perubahan warna, juga dapat dilihat dari ukuran diameter telur. Hasil penelitian ini menunjukkan bahwa telur rajungan semakin matang berdasarkan ukuran diameter berurutan mulai warna kuning, orange, coklat dan abu kehitaman.

Rajungan betina bertelur yang didapatkan selama penelitian ini berdasarkan warnanya sejumlah 200 ekor dengan warna kuning, 266 ekor dengan warna orange, 132 ekor dengan warna coklat dan 118 ekor dengan warna abu kehitaman. Hasil yang didapatkan tersebut menunjukkan selama periode bulan Juli sampai dengan September 2019 rajungan betina matang telur yang mampu mencapai tingkat kematangan telur warna hitam hanya kurang lebih $16 \%$ saja. Jumlah tersebut tergolong minim yang diduga disebabkan oleh kurangnya selektifitas nelayan rajungan Desa Betahwalang dalam aktifitas penangkapan. Penangkapan yang kurang selektif apabila terus dilakukan akan menyebabkan terganggunya proses rekruitmen rajungan di perairan. Menurut Ikhwanuddin et al. (2012), adanya perubahan suhu perairan yang semakin meningkat dapat mempercepat proses kematangan gonad dan pemijahan bagi rajungan. Faktor lain yang dapat mempengaruhi proses kematangan telur rajungan adalah aktifitas penangkapan.
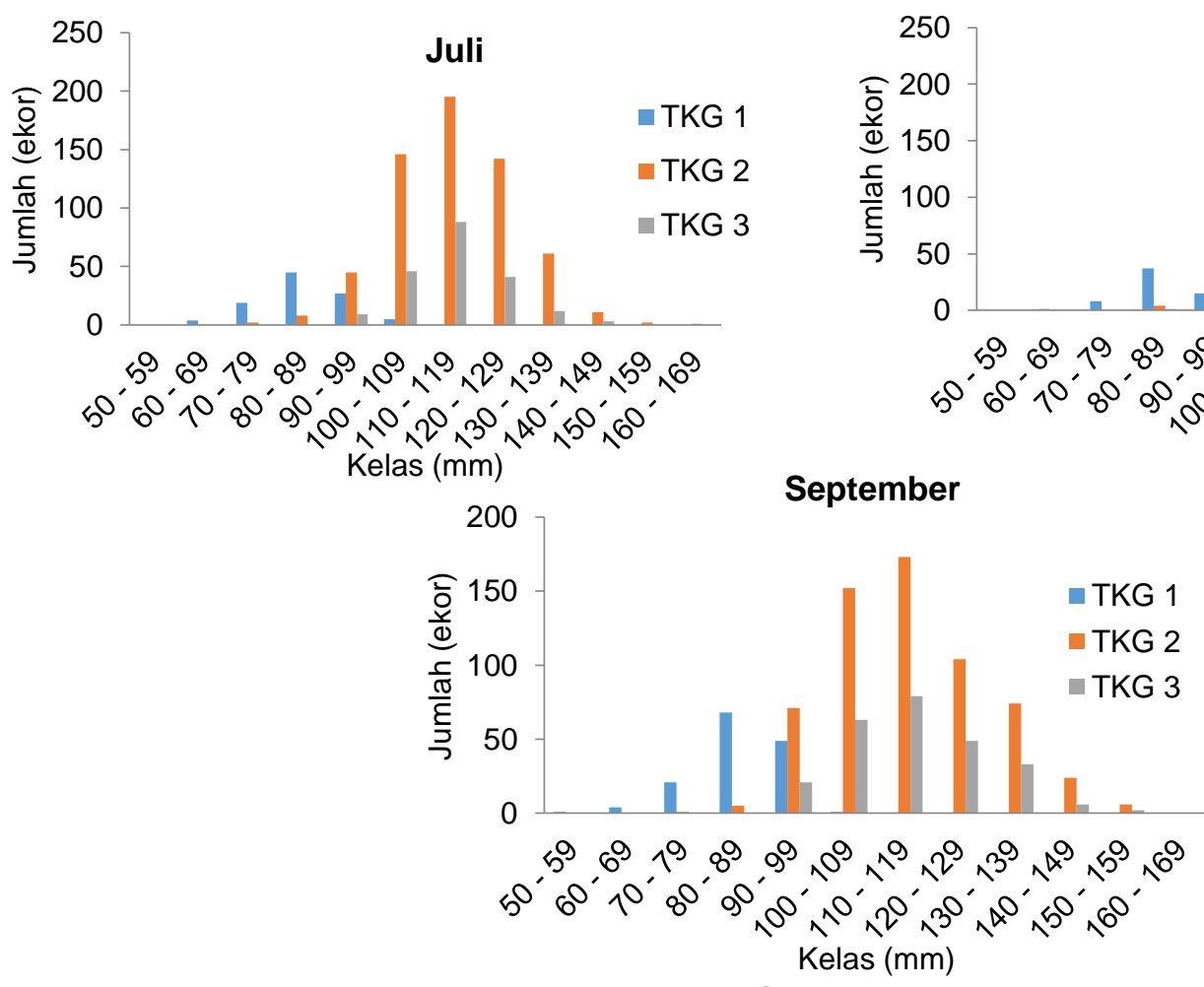

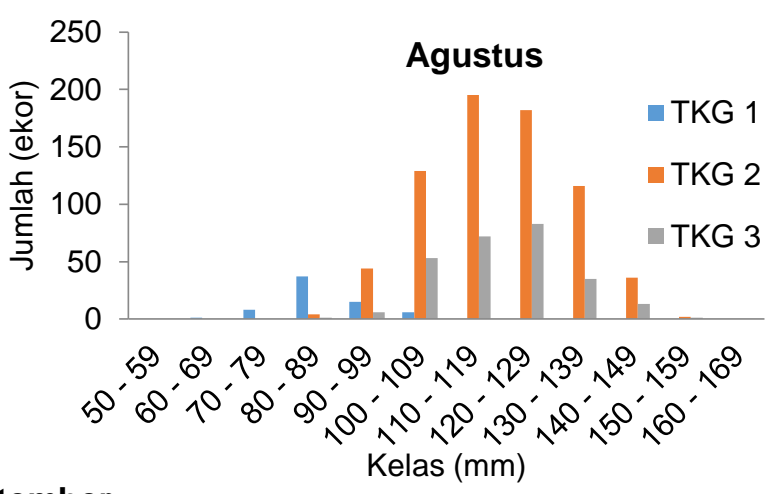

Kelas $(\mathrm{mm})$

Gambar 3. Distribusi Tingkat Kematangan Gonad Rajungan Betina berdasarkan Kelas Lebar Karapas Hasil Tangkapan Nelayan dari Perairan Betahwalang, Demak 


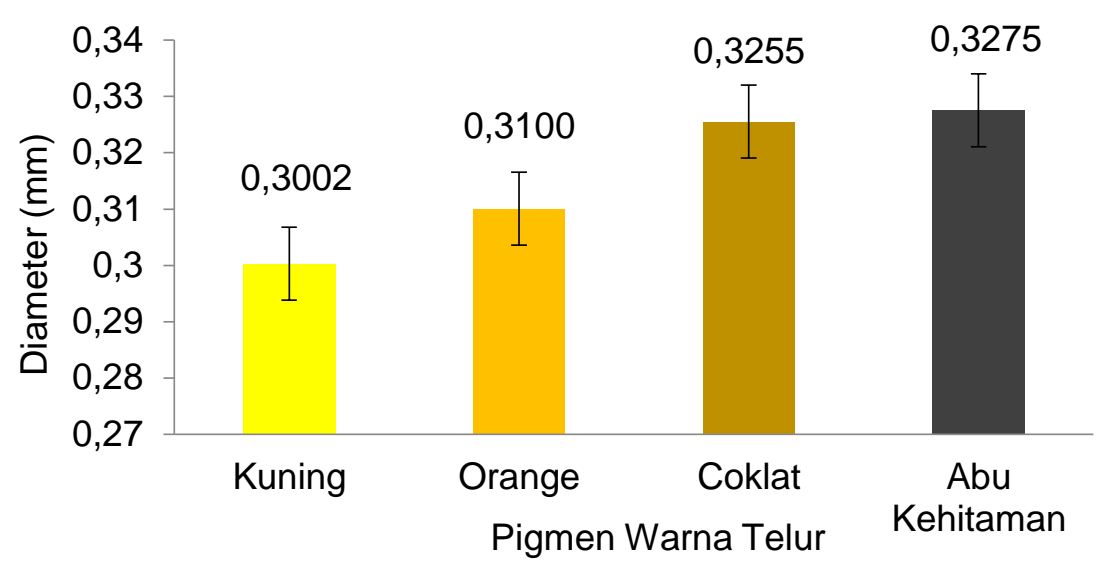

Gambar 4. Tingkat Kematangan Telur Rajungan Betina berdasarkan Ukuran Diameter Telur

Tabel 4. Hubungan Fekunditas dengan Lebar Karapas, Berat Tubuh dan Berat Telur Rajungan Betina Hasil Tangakapan Nelayan dari Perairan Betahwalang, Demak

\begin{tabular}{ccccc}
\hline Hubungan & Persamaan Linier & $r$ & $\mathrm{R}^{2}$ & Taraf Nyata \\
\hline $\mathrm{F}-\mathrm{Lk}$ & $\mathrm{F}=19.120 \mathrm{Lk}-2 \times 10^{-6}$ & 0,811 & 0,657 & $\mathrm{P} \leq 0,05$ \\
$\mathrm{~F}-\mathrm{B}$ & $\mathrm{F}=4.501 \mathrm{~B}+13.206$ & 0,769 & 0,591 & $\mathrm{P} \leq 0,05$ \\
$\mathrm{~F}-\mathrm{Bt}$ & $\mathrm{F}=37.782 \mathrm{Bt}-8.396$ & 0,842 & 0,710 & $\mathrm{P} \leq 0,05$ \\
\hline
\end{tabular}

Fekunditas dan tingkat kematangan gonad (TKG) merupakan aspek penting dalam kajian biologi reproduksi rajungan. Menurut Ernawati et al. (2014), pengetahuan mengenai fekunditas rajungan merupakan faktor yang sangat penting dalam manajemen stok rajungan. Hasil penelitian ini didapatkan fekunditas telur rajungan betina paling rendah kurang lebih 333.333 butir telur dengan lebar karapas $95 \mathrm{~mm}$, sedangkan jumlah telur tertinggi kurang lebih 1.605 .769 butir telur dengan ukuran lebar karapas $151 \mathrm{~mm}$. Variasi fekunditas telur rajungan betina dapat disebabkan oleh beberapa faktor yang berpengaruh seperti perbedaan ukuran, umur dan struktur populasi rajungan, ketersediaan makanan dan kondisi habitat.

Hubungan fekunditas dengan lebar karapas, berat tubuh dan berat telur pada penelitian ini ditemukan bersifat nyata, berkorelasi positif dan kuat, yang artinya jika ukuran tubuh dan berat telur rajungan semakin meningkat, maka fekunditas atau jumlah telur pada individu tersebut akan semakin banyak. Hasil persamaan regresi linier antara fekunditas dengan berat telur lebih tepat digunakan, karena nilai koefisien determinasi $\left(R^{2}\right)$ memiliki nilai yang lebih tinggi. Menurut Soundarapandian dan Tamizhazhagan (2009), produksi telur rajungan memiliki hubungan langsung dengan berat tubuh dan pertumbuhan lebar karapas. Rajungan betina yang memiliki ukuran lebih besar akan menghasilkan jumlah telur lebih banyak, sebaliknya rajungan betina dengan ukuran lebih kecil jumlah telurnya juga lebih sedikit. Fekunditas telur rajungan betina yang didapatkan pada penelitian ini berbeda dengan lokasi lain seperti di Perairan Pati yang berkisar antara $35.214-1.347 .029$ butir telur (Ernawati et al., 2014) dan di Perairan Teluk Lasongko yang berkisar antara 556.248 - 869.261 butir telur (Hamid et al., 2015). Hasil tersebut menunjukkan bahwa selain faktor ukuran individu rajungan, fekunditas telur juga di pengaruhi oleh perbedaan lokasi maupun musim. Fekunditas telur rajungan betina dari Perairan Betahwalang yang didapatkan memiliki jumlah relative banyak, sehingga diharapkan peluang terjadinya rekruitmen atau peremajaan rajungan memiliki kemungkinan yang tinggi.

Parameter kondisi lingkungan memiliki peran penting pada siklus kehidupan setiap makhluk hidup dan berbagai jenis biota yang ada di berbagai ekosistem, hal tersebut juga berlaku pada rajungan ( $P$. pelagicus). Suhu merupakan salah satu faktor lingkungan yang mempengaruhi kehidupan rajungan. Hasil pengamatan parameter suhu pada penelitian ini didapatkan kisaran suhu $28,5-30,1^{\circ} \mathrm{C}$. Suhu air yang didapat selama penelitian ini sudah cukup optimal untuk menunjang siklus hidup dan pertumbuhan rajungan. Peranan suhu perairan sangat menonjol 
terhadap aktifitas rajungan, dimana rajungan lebih aktif bergerak pada malam hari ketika suhu tidak terlalu tinggi dan aktifitas pemijahan rajungan umumnya terjadi saat musim kemarau. Suhu perairan yang didapatkan masih sesuai dalam rentang optimum suhu untuk menunjang kehidupan rajungan yaitu berkisar antara $27-32^{\circ} \mathrm{C}$ (Juwana, 1997). Suhu perairan yang didapatkan pada penelitian ini lebih rendah dibandingkan suhu di perairan Salemo oleh Nurdin et al. (2016) yang berkisar antara $29-32^{\circ} \mathrm{C}$.

Nilai salinitas selama penelitian berkisar antara 32-39 ppt. Nilai salinitas pada di Perairan Betahwalang ini masih termasuk ke dalam rentang optimum untuk rajungan. Menurut Juwana (1997), pada salinitas 28 - 32 ppt umumnya ditemukan rajungan dengan ukuran kecil, sedangkan pada kisaran salinitas 35 - 40 ppt banyak ditemukan rajungan dewasa matang gonad dan betina bertelur. Salinitas perairan memberikan pengaruh terhadap siklus hidup rajungan, dimana rajungan betina akan melakukan migrasi ke perairan dengan salinitas yang lebih tinggi untuk menetaskan telur-telurnya. Penelitian sebelumnya oleh Edi et al. (2018) di Perairan Betahwalang, menyatakan rajungan matang gonad dan betina bertelur banyak ditemukan pada kisaran kedalaman 21 sampai 30 meter dengan kadar salinitas 34-37 ppt.

Kisaran oksigen terlarut perairan yang didapatkan dari hasil penelitian adalah berkisar antara 4,8-12 mg/L. Kandungan oksigen terlarut di lokasi penelitian ini masih memenuhi kriteria untuk kehidupan rajungan, sesuai dengan pernyataan Juwana (1997) yang menyatakan bahwa kebutuhan oksigen untuk kehidupan rajungan adalah $>5 \mathrm{mg} / \mathrm{L}$. Nilai $\mathrm{pH}$ yang didapatkan dari hasil penelitian adalah berkisar antara 6,11-6,60. Penelitian sebelumnya yang dilakukan oleh Hamid et al. (2015) di perairan Teluk Lasongko berkisar antara 7,45-8,74. Nilai pH dan oksigen terlarut pada penelitian ini masih tergolong sebagai nilai optimum bagi kehidupan rajungan, yang didukung oleh pernyataan Sunarto (2012) bahwa rajungan merupakan biota yang mampu beradaptasi dan tahan terhadap kondisi perairan yang ekstrim.

\section{KESIMPULAN}

Pola pertumbuhan rajungan bersifat allometrik, dengan rajungan jantan bersifat allometrik positif dan betina cenderung bersifat allometrik negatif. Kelimpahan rajungan yang didapatkan adalah betina sebanyak 2.960 ekor (55\%) dan jantan 2.388 ekor (45\%). Rasio rajungan jantan dan betina relatif seimbang, tetapi rajungan betina mendominasi pada bulan Agustus yang diduga berkaitan dengan musim pemijahan. Komposisi tingkat kematangan gonad rajungan betina didominasi oleh betina matang gonad (TKG 2), dengan jumlah tertinggi pada bulan Agustus. Terdapat ukuran rajungan kecil $(<100 \mathrm{~mm})$ yang sudah matang gonad bahkan bertelur, yang diduga disebabkan adanya tekanan oleh aktifitas penangkapan.

\section{DAFTAR PUSTAKA}

Damora, A., \& Nurdin, E.. 2016. Beberapa Aspek Biologi Rajungan (Portunus pelagicus) di Perairan Labuhan Maringgai, Lampung Timur. BAWAL, 8 (1): 13-20.

de Lestang, S., Hall, N.G., \& Potter, I.C. 2003. Reproductive Biology of The Blue Swimmer Crab (Portunus pelagicus, Decapoda: Portunidae) in Five Bodies of Water on The West Coast of Australia. Fish Bulletin, 101(1):745-757.

Edi, H.S.W., Djunaedi, A., \& Redjeki, S. 2018. Beberapa Aspek Biologi Reproduksi Rajungan (Portunus pelagicus) di Perairan Betahwalang Demak. Jurnal Kelautan Tropis, 21(1):55-60.

Ernawati T., Boer, M. \& Yonvitner. 2014. Biologi Populasi Rajungan (Portunus pelagicus) di Perairan Sekitar Wilayah Pati, Jawa Tengah. BAWAL, 6 (1): 31-40.

Hamid, A., Yusli, W., Djamar, T.F.L. \& Etty, R. 2015. Fekunditas dan Tingkat Kematangan Gonad Rajungan (Portunus pelagicus) Betina Mengerami Telur di Teluk Lasongko, Sulawesi Tenggara. Bawal, 7(1):43-50.

Ikhwanuddin, M., Azra, M., Aimuni, H.S. \& Abol-Munafi, A.B. 2012. Fecundity, Embryonic and Ovarian Development of Blue Swimming Crab, Portunus pelagicus (Linnaeus, 1758) in Coastal Water of Johor, Malaysia. Pakistan Journal of Biological Sciences, 15(15):720-728.

Juwana, S. 1997. Tinjauan Tentang Perkembangan Penelitian Budidaya Rajungan (Portunus pelagicus, Linn). Oseana, 22(4):1-12. 
Juwana, S. 1999. Pengaruh Pencahayaan, Salinitas dan Suhu Terhadap Kelulushidupan dan Laju Pertumbuhan Benih Rajungan (Portunus pelagicus). Jurnal Ilmu Kelautan, 4 (4): 194-204.

Kembaren, D.D., Ernawati, T. \& Suprapto. 2012. Biologi dan Parameter Populasi Rajungan (Portunus pelagicus) di Perairan Bone dan Sekitarnya. Jurnal Penelitian Perikanan Indonesia, $18(4): 273-281$.

Kunsook, C., Nantana, G. \& Nittharatana, P. 2014. A Stock Assessment of The Blue Swimming Crab Portunus pelagicus (Linnaeus, 1758) for Sustainable Management in Kung Krabaen Bay, Gulf of Thailand. Tropical Life Sciences Research, 25(1):41-59.

Ningrum, V.P., Ghofar, A. \& Ain, C. 2015. Beberapa Aspek Biologi Perikanan Rajungan (Portunus pelagicus) di Perairan Betahwalang dan Sekitarnya. Jurnal Saintek Perikanan, 11(1):62-71.

Nurdin, M.S., Ali., S.A. \& Yanuarita, D.. 2016. Sex Ratio and Size at First Maturity of Blue Swimming Crab (Portunus pelagicus) at Salemo Island, South Sulawesi. Jurnal IImu Kelautan, $21(1): 17-22$.

Peraturan Kementerian Kelautan dan Perikanan. 2016. Peraturan Menteri Kelautan dan Perikanan Nomor 56 Tahun 2016 tentang Penangkapan Lobster (Panulirus spp.), Kepiting (Scylla spp.), dan Rajungan (Portunus spp.). Jakarta. Kementerian Kelautan dan Perikanan. 8 hal.

Soundarapandian, H. \& Tamizhazhagan, T. 2009. Embryonic Development of Commercially Important Swimming Crab Portunus pelagicus (Linnaeus). Current Research Journal of Biological Sciences, 1(3): $106-108$.

Sumpton, W.D., Potter, M.A. \& Smith, G.S. 1994. Reproductions and Growth of The Commercial Sand Crab (Portunus pelagicus) in Moreton Bay Queensland. Asian Fisheries Science, 7 (2): 103-133.

Sunarto. 2012. Karakteristik Bioekologi Rajungan (Portunus pelagicus) di Perairan Laut Kabupaten Brebes. Ilmu Kelautan, Institut Pertanian Bogor. Bogor. 210 hal.

Zairion., Wardiatno., Y., Fachrudin, A. \& Boer, M. 2014. Distribusi Spasio-Temporal Populasi Rajungan (Portunus pelagicus) Betina Mengerami Telur di Perairan Pesisir Lampung Timur. Bawal, 6 (2): 95-102. 